\title{
TRANSINTERNALISASI BUDAYA PENDIDIKAN ISLAM: MEMBANGUN NILAI ETIKA SOSIAL DALAM PENGEMBANGAN MASYARAKAT
}

\author{
Imam Mawardi \\ Universitas Muhammadiyah Magelang, Jl. Mayjend Bambang \\ Soegeng Mertoyudan Km 5 Magelang Jawa Tengah 56172 \\ e-mail: mawardi_rz@yahoo.co.id
}

\begin{abstract}
Abstrak: Pendidikan Islam adalah pelestari dan penyambung nilai-nilai etika sosial masyarakat. Oleh karena itu, paradigma yang perlu dibangun adalah bagaimana melakukan menyesuaikan pendidikan Islam dengan perubahan-perubahan sosial berdasarkan sifat kemodernan yang dilandasi ketentuanketentuan moral, sebagaimana yang digariskan dalam ajaran Islam. Dengan etika sosial, pendidikan Islam menjadi jembatan dari percaturan global di seluruh aspek kebudayaan masyarakat, dimulai dari keluarga sampai ke lingkungan yang lebih pelik dan luas. Dengan demikian, sistem pendidikan Islam yang perlu diwujudkan ialah yang bersifat interdisipliner, multidisipliner dan transdisipliner dengan kebijakan yang saling mengikat antara pemenuhan nilai-nilai sosial, agama, budaya dan kebutuhan pasar.
\end{abstract}

Abstract: Islamic education is a conservationist and connector for socio-ethical values of society. Therefore, the paradigm which should be established is how to adapt Islamic education with social changes based on the modernity with moral values as outlined in the teachings of Islam. With social ethics, Islamic education can became a bridge for the global issues in all aspects of community culture, beginning from family to the larger and more complicated communities. Hence. the system of Islamic education which should be actualized is that related to interdisciplinary, multi-disciplinary and transdisciplinary subject with the policy of mutual binding between the compliance of socio-religio cultural values and the needs of the market.

Kata Kunci: transinternalisasi, pendidikan Islam, etika sosial, masyarakat 


\section{PENDAHULUAN}

Perubahan-perubahan yang terjadi dalam kehidupan masyarakat modern membawa dampak bagi sinergitas kebutuhan dan keinginan dalam mewujudkan sebuah harapan, meskipun harapan tersebut belum tentu mampu memuaskan di berbagai aspeknya. Salah satu aspek adalah kebutuhan akan sebuah etika sebagai piranti kearifan dalam perkembangan masyarakat. Kearifan tradisional menjadi "barang langka" dalam mewujudkan standar pergaulan hubungan kemasyarakatan. Dalam hal ini, pendidikan Islam diharapkan menjadi pioneer yang mampu memberikan pencerahan terhadap kesadaran keberlangsungan sejarah dalam pembudayaan etika sosial sebagai landasan berpijak dalam pemberdayaan masyarakat. Karena itu, pendidikan seharusnya tidak diletakkan dan dikelola sebagai paket pengembangan jiwa atau kepribadian hingga keterampilan semata, tetapi pemberian fasilitas bagi setiap orang untuk bisa mengalami dan menyelesaikan sebanyak mungkin problemproblem yang terjadi pada kehidupannya dan masyarakat. Dengan demikian, tujuan pendidikan seharusnya diorientasikan bukan sekedar sebagai prestasi otak, tetapi juga kualitas spiritual dan religius dalam menempatkan posisi diri sebagai bagian dari masyarakat serta pemihakan pada nilai-nilai kemanusiaan. ${ }^{1}$ Mengingat pendidikan Islam merupakan refleksi dari ajaran Islam yang berupaya merealisasikan keseimbangan antara kepentingan duniawi dan kepentingan ukhrawi ${ }^{2}$, individu dan social, secara simultan harus memperhatikan kepentingan individu dan masyarakat, tidak mengutamakan salah satunya, Aalasannya ialah karena pendidikan Islam menanamkan fadhilah (keutamaan) kepada individu agar menjadi sumber kebaikan bagi masyarakat dan bertanggung jawab di dalamnya berdasarkan kaidah saling menolong dan menolak individualisme.

\footnotetext{
${ }^{1}$ Abdul Munir Mulkhan, Nalar Spiritual Pendidikan Islam: Solusi Problem Filosofis Pendidikan Islam (Yogyakarta: Tiara Wacaana, 2002), h. 166.

${ }^{2}$ Q.S. al-Qashash (28): 77.
} 
Transinternalisasi budaya pendidikan Islam adalah bentuk 'penularan' nilai-nilai yang dapat memberi kontribusi pemberdayaan masyarakat melalui proses kulturisasi (pembudayaan) yang di dalamnya melekat secara in heren sebuah ikatan moral. Proses kulturisasi ini dimulai dengan pengembangan manusia sebagai individu, manusia dalam keluarga, dan manusia dalam percaturan dunia dengan meletakkan etika sosial sebagai standar moral dalam berinteraksi. Oleh karena itu, dalam usaha pengembangan masyarakat, sistem pendidikan Islam memerlukan strategi untuk memudahkan proses transmisi kepada cita-cita yang diharapkan, melalui studi terhadap paradigma pengembangan masyarakat; ide-ide sentral pendidikan Islam dan sasaran pengembangan masyarakat.

\section{ARTI PENTING TRANSINTERNALISASI BUDAYA PENDIDIKAN ISLAM}

Transinternalisasi budaya pendidikan Islam merupakan proses penghayatan secara inheren antara nilai-nilai perekat budaya melalui pendidikan Islam sehingga menjadi kesadaran kolektif yang mengikat dan diwujudkan dalam aturan-aturan etika dalam memberdayakan masyarakat. Transinternalisasi pada pokoknya adalah memadukan perubahan-perubahan struktural dan usaha inovatif sehingga keterkaitan antara fungsi pendidikan dan masyarakat tetap terpelihara menghadapi isu-isu yang berkembang dalam masyarakat oleh fleksibilitas, kepekaan dan komitmennya terhadap perkembangan masyarakat itu sendiri dalam mewujudkan tujuan pendidikan Islam membentuk peradaban masyarakat.

Budaya pendidikan Islam merupakan perpaduan nilai-nilai, keyakinan, asumsi, pemahaman, dan harapan-harapan yang diambil dari inti ajaran Islam dan diyakini warga masyarakat serta dijadikan pedoman bagi perilaku dan pemecahan masalah (internal dan eksternal) yang mereka hadapi. Dengan perkataan lain, budaya pendidikan Islam merupakan semangat, sikap, dan 
perilaku pihak-pihak yang terkait dengan masyarakat secara konsisten dalam meyelesaikan berbagai masalah. ${ }^{3}$

Di dalam masyarakat terdapat faktor-faktor yang membuat proses humanisasi oleh pendidikan menjadi sulit atau menjadi mudah. Hal ini disebabkan oleh infleksibilitas lingkungan social yang berpengaruh besar terhadap pembentukan kepribadian. Infleksibilitas lingkungan ialah "sejauhmana lingkungan bertentangan dengan kebutuhan dan tuntutan pribadi”. Individu akan hidup harmonis bersama lingkungannya selama lingkungan itu mampu memenuhi kebutuhannya. ${ }^{4}$

Perlunya transinternalisasi budaya pendidikan Islam disebabkan antara lain hilangnya perhatian nilai-nilai etika dari out put pendidikan dalam masyarakat. Tatakrama dalam bermasyarakat mulai luntur, tiada lagi batas sopan santun. Hal ini menyangkut seluruh tata kehidupan, baik dalam hubungan sosial, ekonomi, politik, maupun budaya. Tumbuhnya sifat individualis mewarnai arogansi perilaku tanpa mengenal kepedulian sosial. Sifat kemanusiaan mengalami distorsi yang mewarnai egoisme individual dan sentimen kelompok yang membabi buta. Pendidikan hanya bermakna bagi pemenuhan intelektual, dan kurang dalam penanaman sikap.

Untuk menjembatani berbagai persoalan, pendidikan Islam menawarkan prinsip-prinsip transinternalisasi yang menempatkan agama sebagai norma yang mutlak, yang memberikan asumsi-asumsi etis dan spiritual. Implikasinya secara filosofis, pendidikan Islam merupakan proses pembebasan akal dari angan-angan dan pikiran yang kotor, pembebasan jiwa dari rasa takut dan pembudakan, dan pada waktu yang sama

\footnotetext{
${ }^{3}$ Muhaimin, Rekonstruksi Pendidikan Islam: Dari Paradigma Pengembangan, Manajemen Kelembagaan, Kurikulum hingga Strategi Pembelajaran (Jakarta: PT RajaGrafindo Persada, 2009), h. 308.

${ }^{4}$ Hery Noer Aly dan Munzier S., Watak Pendidikan Islam (Jakarta: Friska Agung Insani, 2003), h. 176.
} 
pembebasan fisik dari ketundukan kepada diri dan syahwat. ${ }^{5}$ Pendidikan Islam dengan demikian merupakan metode yang tepat untuk mengubah sikap dan menuntun anggota masyarakat untuk menerima dan memulai perubahan sosial. ${ }^{6}$ Setiap masyarakat menginginkan warganya sesuai dengan cita-cita yang diharapkan, tetapil sistem yang diterapkan antara masyarakat yang satu dengan yang lainnya berbeda, sehingga perlu adanya hubungan yang kuat antara cita-cita dari masyarakat dan prinsipprinsip pendidikan.Islam sebagai pandangan hidup dan bukan sistem ritual semata, cita-cita dan prinsip yang digunakan pendidikan Islam harus selalu tetap mengacu pada prinsip-prinsip Alquran dan sunah Rasulullah ${ }^{7}$

Secara sosiologis, prinsip transinternalisasi budaya pendidikan Islam adalah suatu proses yang terus berubah dan dapat diukur sesuai dengan perubahan-perubahan eksternal yang mengatur masyarakat. Hal ini mengisyaratkan secara tidak langsung bahwa pendidikan harus direncanakan sedemikian rupa agar pendidikan memiliki sebuah pola interdisipliner yang seimbang $^{8}$ sehingga mampu mewujudkan suatu kesadaran masyarakat yang berkesadaran religius dan mengutamakan moral yang diserta sikap ilmiah pengembangan, pemeliharaan dan transmisi nilai-nilai yang dibenarkan dan diterima masyarakat. Dengan demikian, pendidikan Islam diharapkan dapat berperan secara dialektis-transformatif dalam konteks sosio-budaya yang

${ }^{5}$ Ibid, h. 154

${ }^{6}$ Bandingkan dengan sistem pendidikan Barat Modern yang memberikan peneekanan yang berlebihan pada akal dan rasionalitas dan menganggap sepele nilai spiritual. Pendidikan lebih bersifat antroposentris daripada teosentris, sehingga melahirkan sikap uindividualisme dan skeptisme. Untuk uraian selanjutnya, lihat Syed Sajjad Husein dan Syed Ali Ashraf, Menyongsong Keruntuhan Pendidikan Islam, diterjemahkan dan disunting oleh Rahmani Astuti (cet. ke- 5, Bandung: Gema Risalah Press, 1994), h. 2.

${ }^{7}$ Abdul Rahman Salih Abdullah, Education Theory of Quranic Outlook (Makkah al-Mukarramah: Umm al-Qura University, 1402/1982), h. V-VI.

${ }^{8}$ Ali Ashraf, Horison Baru Pendidikan Islam, terj. Sari Siregar (t.t.p.: Pustaka Firdaus, 1993), h. 3. 
senantiasa menunjukkan perubahan secara kontinun, sejalan dengan adanya sofistifikasi budaya dan peradaban umat manusia. Dalam konteks ini, pendidikan perlu ditempatkan sebagai open system yang siap melakukan dialog kultural dengan perkembangan. ${ }^{9}$

Perubahan-perubahan pada tingkat konseptual menurut Don Adams (1970) menggunakan system approach (pendekatan sistem) yang relavan bagi transformasi pendidikan. Sebagaimana digambarkan Azyumardi Azra $^{10}$ dalam konteks modernisasi pendidikan Islam di Indonesia.

Variabel pertama, input dari masyarakat ke dalam sistem pendidikan, yaitu:

- Ideologi-normatif. Orientasi-orientasi ideologis tertentu yang diekspresikan dalam norma-norma nasional. Dalam kerangka ini, pendidikan dipandang suatu instrumen terpenting bagi pembinaan "nation building". Sangat boleh jadi orientasi "ideology" lama-katakanlah Islam-lambat atau cepat tergeser oleh orientasi nasional baru tadi. Atau setidaknya, terjadi semacam situasi anomaly atau bahkan kisis identitas ideologis.

- Mobilisasi politik: kebutuhan bagi moderenisasi dan pembangunan menuntut sistem pendidikan untuk mendidik, mempersiapkan dan menghasilkan kepemimpinan modern dan innovator yang dapat memelihara bahkan meningkatkan momentum pembangunan.

- Mobilisasi ekonomi: kebutuhan akan tenaga kerja yang handal menuntut sistem pendidikan untuk mempersiapkan anak didik menjadi SDM yang unggul dan mampu mengisi berbagai

${ }^{9}$ Tobroni dan Syamsul Arifin, Islam, Pluralisme Budaya dan Politik: Refleksi Teologi Untuk Aksi dalam Keberagaman dan Pendidikan (Yogyakarta: Sipress, 1994), h. 111.

${ }^{10}$ Azyumardi Azra, Pendidikan Islam: Tradisi dan Modernisasi Menuju Milenium Baru (Jakarta: Logos Wacana Ilmu, 1999), h. 32-36. 
lapangan kerja yang tercipta dalam proses pembangunan. Dalam konteks ini, lembaga-lembaga pendidikan Islam tidak memadai lagi sekedar menjadi lembaga "transfer" dan "transmisi" ilmu-ilmu Islam, tetapi sekaligus juga harus dapat memberikan ketrampilan (skill) dan keahlian (abilities).

- Mobilisasi sosial: peningkatan harapan bagi mobilitas sosial dalam modernisasi menuntut pendidikan untuk memberikan akses dan venue ke arah tersebut. Pendidikan Islam, dengan demikian tidak cukup lagi sekedar pemenuhan kewajiban menuntut ilmu belaka; tetapi harus juga memberikan modal dan dengan demikian kemungkinan akses bagi peningkatan sosial.

- Mobilisasi kultural: Modernisasi yang menimbulkan perubahan-perubahan kultural menuntut sistem pendidikan untuk mampu memelihara stabilitas dan mengembangkan warisan kultural yang kondusif bagi pembangunan. Dalam konteks pendidikan Islam khususnya pesantren yang mempunyai "sub-kultur" sendiri yang khas itu, semua ini berarti "penilaian ulang" terhadap lingkungan kulturalnya tersebut.

Variabel kedua, transformasi sistem pendidikan, yaitu:

- Modernisasi administratif: modernisasi menuntut differensiasi sistem pendidikan untuk mengantisipasi dan mengakomodasi berbagai kepentingan differensiasi sosial, teknik dan manajerial. Antisipasi dan akomodasi tersebut haruslah dijabarkan dalam bentuk formulasi, adopsi, dan implementasi kebijaksanaan pendidikan dalam tingkat nasional, regional, dan lokal. Dalam konteks ini, sistem dan lembaga pendidikan Islam, khususnya pesantren, pada umumnya baru mampu melakukan reformasi dan modernisasi administratif secara terbatas. Kebanyakan masih berpegang pada kerangka "administratif tradisional". 
- Differensiasi struktural: pembagian dan difersifikasi lembagalembaga pendidikan sesuai dengan fungsi-fungsi yang akan dimainkannya. Dalam hal ini, sistem pendidikan Islam, seperti pesantren, haruslah memberikan peluang dan bahkan mengharuskan pembentukan lembaga-lembaga pendidikan khusus yang diarahkan untuk mengantisipasi differensiasi sosial-ekonomi yang terjadi, misalnya melalui pesantran pertanian, pesantren politeknik, dan sebagainya.

- Ekspansi kapasitas: perluasan sistem pendidikan untuk menyediakan pendidikan bagi sebanyak-banyaknya peserta didik sesuai kebutuhan yang dikehendaki berbagai sektor Masyarakat.

Variabel ketiga, out put pendidikan yang merupakan input bagi masyarakat adalah sebagai berikut:

- Perubahan sistem nilai: dengan memperluas "peta kognitif" peserta didik, maka pendidikan menanamkan nilai-nilai yang merupakan alternatif bagi sistem nilai tradisional. Perluasan wawasan ini akan merupakan pendorong bagi tumbuh dan berkembangnya "semangat untuk berprestasi" (need of achievement), dan mobilitas sosial. Persoalannya kemudian, sejauh mana sistem dan lembaga pendidikan Islam, khususnya pesantren yang secara sadar mengorientasikan diri pada perluasan "peta kognitif" ini; bahkan sebaliknya terdapat kesan yang kuat bahwa pesantren tetap berkutat pada "normativisme" dan dogmatis lama yang kurang memberikan kesempatan bagi pengembangan kognisi dan kreativitas.

- Out out politik: kepemimpinan modernitas dan inovator-yang dihasilkan sistem pendidikan dapat diukur dengan perkembangan kuantitas dan kekuatan birokrasi sipil-militer, intelektual dan kaderkader administrasi politik lainnya, yang direkrut dari lembagalembaga pendidikan-terutama pada tingkat menengah dan tinggi. 
- Out put ekonomi: dapat diukur tingkat ketersediaan SDM atau tenaga kerja yang terlatih dan siap pakai. Dalam pendidikan Islam belum terlambat link and match yang jelas dan kuat antara sistem dan lembaga pendidikan Islam dengan masalah tenaga kerja yang terlatih dan siap pakai tersebut.

- Out put sosial: dapat dilihat dari tingkat integrasi sosial dan mobilitas peserta didik ke dalam masyarakat secara keseluruhan. Dalam hal ini, integrasi sosial, out put sistem dan lembaga pendidikan Islam kelihatannya relatif berhasil, karena didukung oleh faktor kependudukan Indonesia yang mayoritas muslim. Tetapi dalam hal mobilitas sosial, sistem dan kelembagaan pendidikan Islam kelihatannya belum lagi kelihatan signifikansinya.

- Out put cultural: tercermin dari upaya-upaya pengembangan kebudayaan ilmiah, rasional, dan inovatif; peningkatan peran integratif, agama; dan pengembangan bahasa pendidikan.

Dengan demikian dari proses transformasi pendidikan Islam berdasarkan variabel-variabel di atas, bahwa proses pendidikanmemegang prinsip transformasi-adalah bagaimana pendidikan memberikan suasana yang konduktif bagi pengembangan etos kultural kebangsaan, sehingga terjadilah interaksi dengan lingkungan di sekitarnya. Oleh sebab itulah, pendidikan diartikan sebagai proses kulturisasi (pembudayaan), yakni memasyarakatkan (sosialisasi) nilai-nilai ilmu pengetahuan dan ketrampilan yang berkembang dalam masyarakat ${ }^{11}$ dengan disertai suatu landasan moral "etika sosial", sehingga hasil yang diterapkan dalam masyarakat dari proses transformasi pendidikan Islam akan bercorak humanistic-religius. ${ }^{12}$ Corak ini 137.

${ }^{11}$ Tobroni dan Syamsul Arifin, Islam, Pluralisme, Budaya dan Politik ..., h.

${ }^{12}$ Humanisme-religius dilakukan sebagai ekspresi dari iman yang bersemayam di dada. Dalam Islam, agama keyakinan dan pemikiran, moral mempunyai warna sendiri, kebaikan tidak sama dengan pengorbanan. Hal inilah yang menjadikan nilai-nilai manusia universal. Uraian lebih lengkap, 
akan menjadi dasar prilaku masyarakat dalam mengikuti perkembangan dunia global yang merupakan tantangan dunia pendidikan itu sendiri, bagaimana pendidikan Islam mampu memberi arah yang tepat di dalam mewujudkan masyarakat.

\section{PERAN PENDIDIKAN ISLAM DALAM PENGEMBANGAN MASYARAKAT}

Proses transinternalisasi pendidikan Islam pada dasarnya merupakan proses yang senantiasa berkesinambungan dengan alur perkembangan masyarakat. Masyarakat yang terdidik dan berbudaya merupakan tujuan dari pendidikan Islam itu sendiri, sehingga peranan pendidikan Islam menjadi salah satu kunci utama dalam meningkatkan kesejahteraan masyarakat di segala aspek kehidupannya, baik dari segi sosial, ekonomi, politik, maupun kultural.

Dalam hal peranan pendidikan ini John. C. Bock dalam Education and Development: A Conflict Meaning (1992) sebagaimana yang dikutip Zamroni, mengidentifikasi peran pendidikan tersebut sebagai (1) Memasyarakatkan ideologi dan nilai-nilai sosio-kultural bangsa; (2) Mempersiapkan tenaga kerja untuk memerangi kemiskinan, kebodohan dan mendorong perubahan sosial, dan (3) Untuk meratakan kesempatan dan pendapatan. Peran yang pertama merupakan fungsi politik pendidikan dan dua peran yang lain merupakan fungsi ekonomi. ${ }^{13}$

Berkaitan dengan peranan di atas, titik sentral penekanan yang dilakukan pendidikan Islam, baik yang berfungsi sebagai politik pendidikan ${ }^{14}$ maupun yang berfungsi ekonomi adalah

baca Marcel A Boisard, Humanisme dalam Islam (L' Humanisme de L'Islam), alih bahasa M. Rasjidi (Jakarta:Bulan Bintang, 1980), h. 76.

${ }^{13}$ Zamroni, Paradigma Pendidikan Masa Depan (Yogyakarta: Bigraf Publising, 2000), h. 2-3.

${ }^{14}$ Landasan-landasan politik pendidikan nasional menurut Mashuri adalah pertama, pendidikan harus berpandangan luas dan jauh kedepan; kedua, pembangunan pendidikan harus diintegrasikan dengan rencana pembangunan nasional; ketiga, pendidikan harus bersifat komprehensif, 
menempatkan religiusitas etika sosial sebagai warna yang mendasari segala program pengambilan kebijakan dan tindakan. Dari sikap ini diharapkan adanya kekuatan misi yang menjiwai proses pengembangan masyarakat.

Oleh karenan itu, sistem pendidikan Islam dalam usaha pengembangan masyarakat, memerlukan strategi untuk memudahkan proses transmisi kepada cita-cita yang diharapkan, melalui studi terhadap paradigma pengembangan masyarakat; ide-ide sentral pendidikan Islam dan sasaran pengembangan masyarakat.

\section{Ide-Ide Sentral Pendidikan Islam}

Ilmu pendidikan Islam dikembangkan secara dinamis agar dapat mengikuti progresifitas zaman yang semakin modern. Meskipun demikian, ilmu pendidikan Islam tetap berpegang pada landasan nilai-nilai yang sesuai dengan ajaran Islam. Dalam mengikuti progresifitas inilah ilmu pendidikan Islam bersifat ekslusif dan inklusif.

Bersifat inklusif (tertutup) adalah apabila pendidikan Islam dengan berbagai persoalannya merupakan hal ihwal urusan rumah tangga sendiri, misalnya pendidikan mentransformasikan etika pendidikan, baik dalam arti normatif atau terminal, dalam hal ini pendidikan melakukan dengan pendekatan presepektif. Sedangkan pendidikan dengan sifatnya yang ekslusif (terbuka) yang dipandang sebagai conditio sino qua non ${ }^{15}$ adalah pendidikan dengan berbagai persoalannya bukan semata-mata merupakan urusan rumah tangga sendiri, melainkan dipandang

meliputi pendidikan formal dan non formal; keempat, pendidikan harus integral dengan pengelolaannya; kelima, pembangunan pendidikan harus memperhatikan baik soal-soal kuantitatif maupun soal-soal kualitatif. Mashuri, Kebijaksanaan dan Langkah-Langkah Pembaharuan Pendidikan (Jakarta: Dep. P\&K, 1973), h.13.

${ }^{15}$ Imam Bernadib \& Sutari Imam Bernadib, Beberapa Aspek Substansial Ilmu Pendidikan (Yogjakarta: Andi Offset, 1996), h. 7. 
sebagai hal-hal yang kontekstual terhadap bidang-bidang atau lingkungan yang relevan, misalnya sosialisasi peserta didik.

Karena pendidikan Islam berhubungan dengan perkembangan masyarakat maka perlu memperhatikan teori dan realitas masyarakat, bagaimana tujuan pendidikan itu dapat dicapai? Dalam hal ini, ada dua rumusan das sollen dan das sein. Das Sollen adalah rumusan tentang tujuan dalam arti idealnya dan das sein adalah upaya pencapaiannya. ${ }^{16}$ Dengan demikian teori dapat memberikan deskripsi tentang masyarakat yang ideal (das sollen) dan realitas merupakan pedoman pendidikan dalam praktek (das sein).

Proses pendidikan Islam merupakan hasil das sein yang bergerak menuju das sollen. Karena das sollen pendidikan pada hakekatnya adalah nilai-nilai (values), maka proses pendidikan itu bermuatan nilai (value laoded). Proses pendidikan tidak hanya harus efisien, efektif, dan berkualitas melainkan juga harus dilakukan secara kontinyu. ${ }^{17}$ Jadi, proses pendidikan Islam diwujudkan dalam kerangka perubahan masyarakat, misalnya dari pola hidup yang primitif tanpa aturan menjadi pola hidup modern yang disiplin. Sesuai dengan sifatnya (das sollen) yang bermuatan nilai, perubahan yang diharapkan itu harus selaras dan mengandung kebaikan dan menolak segala bentuk yang sifatnya mengandung kerusakan.

Untuk mencapai das sollen pendidikan Islam, konsep pendidikan bagaimanakah yang sebaiknya dikembangkan sehubungan dengan pengaruh modernisasi ilmu pengetahuan dan teknologi yang setidaknya membawa dampak bagi kebudayaan masyarakat? Untuk menjawab pertanyaan ini terlebih dahulu harus diperhatikan pendekatan tertentu, yaitu konvergensi dan

${ }^{16} I b i d$. , h. 40.

${ }^{17}$ Ibid., h. 41. 
eklektik-inkoporatif ${ }^{8}$ sehingga dengan pendekatan tersebut, dapat diperoleh rumusan sebagai hasil pengamatan terhadap liku-liku manusia dalam masyarakatnya untuk membangun berbagai aspek kehidupan.

Teori-teori pendidikan yang tepat digunakan dalam pemberdayaan masyarakat menurut Imam Bernadib ${ }^{19}$ dikelompokkan ke dalam tiga warna pemikiran untuk memberikan isi bagaimana seharusnya menurut konsepsinya. Adapun teori-teori tersebut adalah teori sumber daya manusia, teori revitalisasi budaya, dan teori rekonstruksionisme.

\section{Teori Sumber Daya Manusia}

Teori sumber daya manusia menempatkan manusia menjadi pandangan utama pendidikan. Teori ini disusun atas dasar progresivisme yang memandang manusia sebagai makhluk yang bebas, aktif, dinamis dan kreatif. Dalam meninjau kebudayaan dan pendidikan, progresivisme mengutamakan tinjauan ke depan dengan komponen pendukungnya,yaitu seleksi natural dan eksperimentalisme. Progresivisme memandang bahwa apa yang menjadi pegangan dalam wawasan seleksi natural dijadikan pegangan bahwa pendidikan menyatu dalam kehidupan. Oleh karena itu, dalam kaitannya dengan eksperimentalisme, pendidikan memberi pelajaran kepada seseorang selain agar orang tersebut dapat menyesuaikan diri terhadap situasi dan kondisi kehidupan nyata, juga agar dapat meningkatkan kualitas kehidupnya dengan mempertinggi moral dan akal budi.

${ }^{18}$ Ibid., h. 63. Di sini dijelaskan bahwa pendekatan konvergensi adalah pendekatan yang meletakkan suatu asas bahwa konsep atau praktek pendidikan yang berasal dari luar dapat diterima sepanjang diperlukan, berguna dan cocok bagi pendidikan di Indonesia. Sedang pendekatan eklektik inkoporatif meletakkan asas bahwa konsep atau praktek pendidikan dari luar dapat diambil sementaa substansinya setelah diadakan telaah atau pemahaman, dengan maksud agar pengambilan itu dapat dilalkukan secara selektif.

${ }^{19}$ Imam Bernadib, Dasar-dasar Kependidikan: Memahami Makna dan Perspektif Beberapa Teori Pendidikan (Jakarta: Ghalia Indonesia, 1996), h. 59. 
Dengan menempatkan manusia sebagai fokus utama, pendidikan diartikan sebagai alat untuk berpikir reflektif ${ }^{\circ}$ dalam melihat fenomena realitas kehidupan yang ada dalam masyarakat. Berdasarkan model berpikir reflektif ini yang juga diberi warna oleh liberalisme dan pragmatisme, ide-ide sentral pendidikan muncul sebagai distribusi demokratis dari rasionalitas dengan perlakuan yang berimbang antara kebebasan dan kesamaan.

\section{Teori Revitalisasi Budaya}

Teori revitalisasi budaya ini timbul dengan pandangan eksistensi manusia dalam hubungannya dengan kebudayaan. Artinya manusia dapat dikatakan manusia bila mempunyai nilai budaya. Dengan demikian pendidikan pada hakekatnya adalah mengkonservasikan dan mengembangkan nilai dan norma kebudayaan yang telah ada dalam pandangan masyarakat. Pandangan tersebut diatas tercermin pada alliran yang menjadi komponennya, yaitu esensialisme dan perenialisme.

Esensialisme memandang kehidupan manusia berada dalam suatu kontak sosial. Prilaku dan tata aturan kehidupannya berada dalam keterkaitan lingkungan kebudayaan dan sosialnya. Atas konsensus bersama manusia membangun tata kehidupan berdasarkan norma dan nilai-nilai yang dijadikan pedoman dan pegangan hidup bagi masyarakat.

\footnotetext{
${ }^{20} \mathrm{Cara}$ berpikir dengan proses cepat antara melihat empiri dan membangun konsep abstraknya biasanya sulit dilacak prosesnya karena cepatnya. Tetapi hasilnya bermutu tinggi bila orangnya cerdas atau orangnya mempunyai antusiasme yang tinggi serta memiliki concern pada permasalahannya. Atau berpikir mondar-mandir antara deduksi-induksi, antara abstraksi-penjabaran, yang berlangsung cepat, tidak dilakukan tuntas, tetapi menghasilkan pemikiran yang berkualitas tinggi, apakah tampil sebagai abstraksi atau tampil sebagai penjabaran. Lihat Noeng Muhadjir, "Glossary" bagian keempat Analisis dan refleksi dalam Pedoman Pelaksanaan Penelitian Tindakan Kelas (PTK) (Dirjen Dikti Depdikbud \& IKIP Yogyakarta, 1996/1997), h. 26. Lihat pula Noeng Muhadjir, Metodologi Penelitian Kebijakan: Telaah Cross Disiplin (Yogyakarta: Rake Sarasin, 1998), h. 29.
} 
Sedangkan perenialisme arti pokok katanya yaitu perenial: hal-hal yang ada sepanjang masa. Sesuai dengan sifatnya yang regresif, artinya kembali kepada kebenaran yang sesungguhnya sebagaimana telah diletakkan dasarnya oleh para filsuf terdahulu, maka hal-hal yang sebenarnya inilah yang perlu digunakan untuk menata kehidupan sekarang. Oleh karena itu, teori revitalisasi budaya bercorak pemikiran pendidikan masa lampau dan sekarang. Artinya, perubahan dan perkembangan dalam masyarakat yang dicita-citakan harus dilandasi oleh komitmen sistem pendidikan yang tegas terhadap pengembangan watak, disiplin dan intelektualisme berdasarkan nilai-nilai luhur kebudayaan masa lalu, sehingga mampu menciptakan tata dan makna bagi eksistensi manusia dalam masyarakat.

\section{Teori Rekonstruksianisme}

Teori rekonstruksianisme memandang pendidikan dalam kaitannya dengan masyarakat, maka dapat diyakini pendidikan mempunyai peranan yang positif dalam merekonstruksi masyarakat. Masyarakat yang direkonstruksi adalah masyarakat yang dapat hidup dalam suasana yang lebih mementingkan kebersamaan daripada kepentingan individu.

Rekonstruksianisme berpendapat bahwa nilai tertinggi dimiliki oleh manusia bila dapat mengembangkan potensinya secara wajar dan alamiah di tengah-tengah masyarakat. Hal ini karena adanya peran kebudayaan dalam mewujudkan tata sosial baru bagi pemerataan kesejahteraan seluruh lapisan masyarakat.

Ketiga teori yang dibicarakan di muka yang telah dirumuskan Imam Bernadib merupakan kajian teori-teori yang berkembang di Barat akibat perkembangan kebudayaan yaitu aufklarung (zaman pencerahan) yang berusaha menempatkan manusia dalam kedudukan yang semestinya, artinya pendidikan mampu memberdayakan potensi kemanusiaan manusia sebagai agent of change dalam pengembangan peradaban. 
Namun, dari ketiga teori tersebut hanyalah bersifat antroposentris semata-mata, artinya sistem pendidikan yang ditawarkan hanyalah berpusat pada peningkatan kualitas manusia tanpa dasar landasan yang jelas sebagai ikatan moral kemanusiaan. Padahal dalam konteks masyarakat, agama sebagai sumber moral dan spirit dalam menata sistem yang ada, termasuk pendidikan. Karena itu, untuk memperluas wawasan wacana kependidikan dan sekaligus mentransformasikan kedalam realitas masyarakat, sehingga nilai-nilai yang ada dalam ketiga teori itu sesuai dengan jiwa pendidikan Islam, maka harus didekati dengan pendekatan theologis-normatif dan historis-phenomenologis. ${ }^{21}$

Theologis-normatif, merupakan pendekatan yang didasarkan norma-norma etika yang bersumber dari nilai-nilai ketuhanan (agama). Norma-norma inilah yang diserap pendidikan Islam dalam membina dan mengembangkan masyarakat. Masyarakat dengan berbagai karakteristik orang-orang di dalamnya merupakan fenomena sosiologis-empiris, maka pendekatan pendidikan Islam dalam hal ini pendekatan historiesphenomenologis digunakan untuk mengasumsikan bahwa dibalik proses kesejarahan ini terdapat rasionalitas dan nilai-nilai ideal yang secara aktif berperan mempengaruhi dan mengarahkan jalannya sejarah yang senantiasa berproses menuju cita-cita yang ideal. $^{22}$ Dalam proses kesejarahan ini, teori pendidikan diuji dan dikaji bagaimana teori ini mampu mengembangkan masyarakat menuju cita-cita masyarakat. Dengan demikian, strategi pendidikan Islam dalam pengembangan masyarakat harus bersifat luwes dan fleksibel tetapi tetap mendasarkan pada kaedah-kaedah normalitas dan religiusitas, hal ini akan mampu mewarnai seluruh dimensi yang berkembang dalam struktur masyarakat.

\footnotetext{
${ }^{21}$ Komaruddin Hidayat, "Ethos Masyarakat Utama" dalam M. Yunan Yusuf, dkk. (Eds.), Masyarakat utama: Konsepsi dan Strategi (Jakarta: PERKASA bekerjasama dengan LPP-PP Muhammadiyah, 1995), h. 61.

${ }^{22}$ Ibid.
} 
Untuk mewarnai dinamika masyarakat sesuai dengan citacitanya yang ideal menuju masyarakat tersebut, diperlukan pemikiran yang berkelanjutan sekaligus bersama itu pula dilakukan tindakan aktif penyelenggara negara dan masyarakat dalam bentuk kebijakan-kebijakan yang terprogram secara berencana. Program secara berencana ini didasari atas prasyarat budaya ${ }^{23}$ yang diletakkan atas konsep etika sosial dan dijiwai atas ajaran formal keagamaan (syariat). Bukan seperti yang terjadi selama ini didasari prasyarat politik yang mengakibatkan kesenjangan budaya penguasa yang cenderung mendewakan konstitusi dan proseduralisme, namun kurang peduli pada realitas obyektif yang ada di dalam dinamika masyarakat yang terus berubah dan berkembang. ${ }^{24}$ Oleh karena itu, konsep strategi yang ditawarkan pendidikan Islam bukan hanya pada batasanbatasan kurikulum kelembagaan formal, tetapi lebih menekankan pada substansi bagaimana etika sosial yang dijiwai nilai-nilai religiusitas itu mampu memberi warna komponen-komponen bangsa, baik melalui bentuk-bentuk hubungan sosial kemasyarakatan maupun melalui perencanaan yang terprogram misalnya pendidikan informal, formal maupun non formal. Untuk itu diperlukan keberanian berinovasi atas dasar efisiensi dan efektivitas secara berkelanjutan.

\section{Sasaran Pengembangan Masyarakat}

Dalam pengembangan masyarakat, nilai-nilai normativitas dan religiusitas sebagai dasar membangun etika sosial yang

\footnotetext{
${ }^{23}$ Prasyarat budaya yang dicirikan oleh kesediaan elite politik, penguasa dan keagamaan untuk meletakkan rakyat bukan sekedar sebagai objek keberlakuan hukum terutama hukum berdasar ajaran agama. Kenudian juga meletakkan Negara dan elite penguasa serta keagamaan sebagai "pelayan" rakyat yang juga sebagai umat pemeluk suatu agama. Lihat Abdul Munir Mulkhan, Kearifan Tradisional: Agama bagi Manusia atau Tuhan, penyunting Anas Hidayat \& Sobirin Malian (Yogyakarta: UII Press, 2000), h. 54-55.

${ }^{24}$ Ibid., h. 56.
} 
mencakup nilai fisik, nilai kultural, nilai sosial ${ }^{25}$ dan nilai religi. Bagi pendidikan nilai-nilai ini adalah merupakan media analisa yang bersifat rasional dan sistematis terhadap proses pengembangan pendidikan yang bertujuan untuk menjadikan pendidikan menjadi lebih efektif dan efisien dalam menanggapi kebutuhan dan tujuan masyarakat. Karena itu, pengembangan masyarakat melalui pendidikan dimulai dengan hal-hal yang prinsip dari potensi masyarakat itu sendiri, bagaimana masyarakat itu bertumbuh, berkembang dan berdaya menghadapi akselerasi peradaban modern. Dengan demikian sasaran pengembangannya harus dimulai dari titik pusat yaitu manusia sebagai individu kemudian manusia dalam keluarga, manusia sebagai anggota masyarakat dan manusia dalam perencanaan dunia.

\section{Manusia sebagai Individu}

Manusia sebagai individu merupakan sasaran pendidikan yang utama dan salah satu prasyarat dalam membentuk masyarakat. Fungsi pendidikan di sini adalah pembinaan pribadi yang mengarah pada pemberdayaan manusia, baik berdaya dari segi intelekltualnya, sikapnya maupun keterampilannya. Pemberdayaan yang diharapkan pendidikan harus diikuti kesadaran diri akan status tanggung jawabnya di tengah budaya global. Kesadaran diri membentuk tazkiyah (karakter) yang merupakan suatu konsep dinamis dan multi dimensional menyangkut beberapa aspek diri ${ }^{26}$, misalnya perasaan, emosi, pengetahuan, nafsu, keinginan dan lain-lain.

Bagi Iqbal, kajian tentang individualitas-yang diistilahkannya dengan "khudi" (kedirian atau individualitas)merupakan kajian yang pokok yang perlu dikaji secara seksama. Karena individualitas atau pun diri (self) bukan sesuatu hal yang

\footnotetext{
${ }^{25}$ F.E Merrill and H.W. Elderdge, Culture and Sociology (New York: Prentice Hall, Inc., 1953), h. 542.

${ }^{26}$ Ziauddin Sardar, Rekayasa Masa Depan Peradaban Muslim, terj. Rahmani Astuti (cet. ke-4; Bandung: Mizan, 1993), h. 237.
} 
tumbuh begitu saja, melainkan merupakan suatu hasil yang dicapai melalui jerih payah dan perjuangan yang sunggugsungguh dan tahan terhadap berbagai kekuatan yang bermunculan dari lingkungan luar maupun terhadap berbagai bentuk kecenderungan penghancuran diri yang tersembunyi di balik manusia itu sendiri. ${ }^{27}$ Bertolak dari pendapat tersebut, maka sasaran pengembangan masyarakat adalah internalisasi nilai-nilai pada individu untuk mengambangkan kepercayaan diri dan meningkatkan kekayaan batin sehingga tidak mudah termabangambing dan terbawa arus peradaban semu. Hal ini karena perkembangan individualitas merupakan suatu proses yang kretif, artinya setiap individu harus berusaha aktif untuk mengadakan aksi dan reaksi yang bertujuan terhadap lingkungan sekitarnya. ${ }^{28}$

Pendidikan Islam memberi makna atas proses kreatif untuk menjaga keserasian antara jasmani-rohani dan dunia-akhirat. Dengan demikian, pengetahuan kehidupan masyarakat secara menyeluruh merupakan modal untuk dapat memformulasikan kadar adaptasi dan dependensi individu terhadap masyarakat ${ }^{29}$,

${ }^{27}$ K. G. Saiyidain, Percikan Filsafat Iqbal Mengenai Pendidikan, terj. M.I. Soelaeman (Bandung: CV. Diponegoro, 1981), h.33. Hal in sebagai bantahan terhadap para penganut ajaran Hegel, Pantheisme, Pseudo Mistisisme yang berpendapat bahwa tujuan tertinggi dan ideal manusia adalah melemyapkan dan meleburkan dirinya dengan yang Mutlak. Lihat ibid., h. 25.

${ }^{28}$ Ibid., h. 35. Untuk memperkaya wacana, baca Mian Muhammad Tufail, Iqbal's Philosophy and Education (Lahore: The Bazm-Iqbal, 1966), h. 127-130.

${ }^{29}$ Dependensi individu dalam beradaptasi dengan-komunitas dibangun atas tiga azas, yaitu pertama, apabila budaya yang menjadi sandaran individu mampu merealisasikan kebutuhannya, maka dia akan menemukan ketenangan kertia bergabung dengan komunitas yang norma dan nilainya dia sepakati. Dia juga merasa senang melakukan suatu pekerjaan serta merasa diterima dengan baik oleh komunitasnya; kedua, Individu hendaknya memiliki kesiapan untuk memainkan peranan sebagai anggota komunitas. Peran individu tersebut tidak hanya berkaitan dengan prilaku tertentu yang dijalankan dari pihaknya, tetapi juga respons tertentu dari pihak lain. Rasa senang individu dengan bersandar kepada komunitas akan memudahkanya untuk menjalankan perannya sebagai anggota komunitas tersebut; dan ketiga, individu hendaknya percaya bahwa 
demikian pula jenis pendidikan dan kadar pengaruhnya terhadap kehidupan masyarakat. Dengan memahami konsep tersebut maka setiap individu dibina untuk membangun strategi hidup yang diwujudkan sebagai cara hidup yang berisi konsep nilai-nilai, patokan-patokan tingkah laku, daya penyesuaian yang tinggi sehingga dapat menjamin kehidupan yang sejati. ${ }^{30}$ Dengan dasar strategi hidup ini, akan mudah tercapai tujuan pendidikan Islam terhadap individu, yaitu untuk membentuk manusia yang sempurna (insan kamil) ${ }^{31}$ yang membawa pengaruh bagi perkembangan masyarakat.

\section{Manusia dalam Keluarga}

Keluarga-sebagaimana kesimpulan pandangan seluruh pakar dari berbagai disiplin ilmu-adalah jiwa masyarakat dan tulang punggungnya.$^{32}$ Oleh karena itu, Islam memberi perhatian yang besar tehadap pembinaan keluarga. Dalam keluarga karakter

pihak lain juga memiliki pemahaman yang sama terhadap norma-norma sosial. Individu tidak akan dapat memainkan peran sosialnya tanpa menggunakan norma bersama yang menjadi landasan pembatasan peran-peran sosial. Kepercayaan dalam menjalankan peran yang disukai menuntut adanya pengalaman yang muncul dari komunitas untuk mengetahui norma-norma, niali-nilai, dan standar-standarnya. Pendek kata, pelaksanaan peran sosial oleh individu didasarkan atas pemahamannya terhadap norma-norma, niali-nilai, dan standar-standar komunitas. Pemahaman ini pada gilirannya didasarkan atas suatu kepercayaaan yang menyebabkan individu bersandar kepada-dan beradaptasinya-dengan komunitas. Lihat Hery Noer Aly dan Munzier S., Watak Pendidikan Islam (Jakarta: Friska Agung Insani, 2003), h. 187-188.

${ }^{30} \mathrm{M}$. Saleh Muntasir, Mencari Evidensi Islam: Analisa Awal Sistem Filsafat, Strategi dan Metodologi Pendidikan Islam (Jakarta: CV. Rajawali, 1985), h. 3 .

${ }^{31}$ Menurut Iqbal, insan kamil adalah insan yang beriman yang di dalam dirinya terdapat kekuatan, wawasan, perbuatan dan kebijaksanaan dan mempunyai sifat-sifat yang tercermin dalam pribadi Nabi saw, berupa akhlak karimah. Tahapan untuk mencapai insan kamil itu diperoleh melalui ketaatan terhadap hukum-hukum Allah, penguasaan ini sebagai bentuk tertinggi kesadaran diri tentang pribadi dan kekhalifahan ilahi. Selanjutnya lihat Dawam raharjo (penyunying), Insan Kamil, Konsep Manusia menurut Islam (cet. ke-2; Jakarta: Temprint, 1989), h. 26.

${ }^{32}$ M. Quraish Shihab, Membumikan Al-Quran: Fungsi dan Peran Wahyu dalam Kehidupan Masyarakat (cet. ke-3; Bandung: Mizan, 1992), h. 253. 
manusia pertama dibentuk, bagaimana prilaku manusia dalam keluarga itu membawa pengaruh bagi perkembangan anak. Bila keluarga dibangun dengan suasana yang penuh kehangatan, kedamaian, kasih sayang dan disiplin tentunya membawa pengaruh yang positif. Sebaliknya, apabila suasana keluarga diliputi percekcokan, kebencian tentu akan membawa pengaruh negatif bagi perkembangan anak.

Kehidupan dengan suasana kekeluargaan selain menjadi salah satu tanda kebesaran Allah, juga merupakan nikmat yang harus dimanfaatkan dan disyukuri ${ }^{33}$ dengan berbagai upaya pembinaan di dalamnya. Adapun jalinan perekat bagi bangunan keluarga adalah hak dan kewajiban yang disyariatkan Allah terhadap ayah, ibu, suami, dan istri serta anak-anak yang tujuannya untuk menciptakan keharmonisan kehidupan rumah tangga yang pada akhirnya menciptakan suasana aman, bahagia dan sejahtera bagi seluruh masyarakat bangsa. ${ }^{34}$

Dengan demikian, keluarga adalah "basis bagi pematangan filsafat hidup sebab dalam keluarga seseorang merenung, memahami arti dirinya dan tanggung jawabnya". ${ }^{35}$ Konsekuensinya seisi keluarga mamahami perannya masingmasing sebagai individu yang bertanggungjawab terhadap tugas kewajiban terutama memimpin diri sendiri sebagaimana dikatakan dalam hadits nabi saw. bahwa setiap orang dari kamu adalah pemimpin dan masing-masing akan dituntut pertanggungjawaban atas kepemimpinannya. ${ }^{36}$

Lebih lanjut, dapat dipahami bahwa sasaran pengembangan masyarakat terhadap keluarga sebagai institusi pertama dan utama pendidikan adalah bertujuan untuk membina anggota keluarga sehingga menjadi keluarga yang komunikatif dan

\footnotetext{
${ }^{33}$ Q.S. al-Rūm (30):21; Q.S. al-Nahl (16):72

${ }^{34}$ Shihab, Membumikan Al-Quran..., h. 7.

${ }^{35}$ Muntasir, Mencari Evidensi Islam...., h. 7.

${ }^{36}$ Hadis riwayat Bukhari dan Muslim dari Ibnu Umar.
} 
akomodatif. Dalam konteks ini, diperlukan perlu perencanaan keluarga (keluarga berencana) sebagai pola alternatif dalam menciptakan kesejahteraan keluarga. Perencanaan keluarga di sini bukan berarti pembatasan kelahiran, tapi menekankan pada sistem manajerialnya, untuk memberdayakan keluarga sehingga dapat menciptakan individu-individu yang berkualitas.

\section{Manusia Sebagai Anggota Masyarakat}

Sebagai anggota masyarakat, pribadi manusia selain sebagai komponen pembangunan, dia juga merupakan figur kontrol. ${ }^{37}$ Artinya, pribadi manusia yang telah dibina sedemiakian rupa dalam keluarganya sehingga mampu memimpin dan membuat inovasi-inovasi terhadap pembangunan. Selain itu, juga memunculkan pribadi-pribadi masyarakat yang berdaya menjaga kontol keseimbangan terhadap pemerintah.

Karena itu, pengembangan masyarakat muslim, menurut Ziaunuddin Sardar, harus berpedoman pada tiga prinsip dasar, yaitu peertama, harus meupakan suatu proses spiritual yang berkaitan dengan sikap ketekunan pribadi yang sedang berkembang, kemandirian dan tindak kerja sama, pengembangan lembaga-lembaga Islam seperti keluarga, masjid dan waqf (dasar kesalehan) dan keikutsertaan serta ikhlas seluruh anggota masyarakat dalam pengembangan kesadaran diri dan kesejahteraan umum bagi setiap individu dalam masyarakat tersebut; kedua, proses kemasyarakatan juga harus merupakan proses pengembangan sosial dan ekonomi. Ini harus diarahkan pada tujuan kemandirian, kemampuan untuk menolong diri sendiri, mengembangkan diri sendiri dan mempertahankan keaslian budaya; dan ketiga, tidak boleh ada usaha yang dijalankan untuk memaksakan satu model tertentu dalam pengembangan masyarakat. Sebaliknya, serangkaian metode harus digunakan agar satu model tertentu muncul dari kalangan

\footnotetext{
${ }^{37}$ Muntasir, Mencari Evidensi Islam..., h. 8.
} 
anggota masyarakat sehingga model tersebut memiliki dasar kongkret untuk meraih masa depan masyarakat itu sendiri. ${ }^{38}$

Jadi sederhananya, untuk mengembangkan masyarakat sasaran yang dituju adalah pemberdayaan masyarakat dengan tujuan kemandirian anggota masyarakat tanpa tekanan apapun melainkan kesadaran sendiri yang dijiwai oleh nilai-nilai religius.

\section{MANUSIA DALAM PERCATURAN DUNIA}

Sasaran pengembangan masyarakat yang terakhir adalah pembinaan manusia menghadapi percaturan dunia global. Pembinaan ini merupakan kelanjutan dari tahapan sebelumnya yang merefleksikan proses pemberdayaan manusia.

Krisis demi krisis mulai bermunculan, dari krisis ekonomi, kepercayaaan hingga krisis identitas mewarnai gerak laju arus globalisasi. Perkembangan ilmu pengetahuan dan teknologi yang bervariasi dan cepatnya informasi global memberi dampak yang memberi warna kepribadian manusia. Adegan kekerasan dan kehidupan glamour yang ditayangkan televisi, semaraknya internet tidak sekedar menyajikan informasi global tetapi juga tempat mencari kepuasan, membentuk pola pikir konsumtif yang brutal.

Pendidikan memiliki keberkaitan erat dengan globalisasi. Pendidikan tidak mungkin menisbahkan proses globalisasi yang akan mewujudkan masyarakat global sehingga diperlukan normanorma universal pendidikan. Hal ini diperlukan untuk mendampingi atau mengiringi lajunya akselerasi budaya. Untuk itulah, diperlukan pendidikan berwawasan global dengan ciri-ciri (1) mempelajari budaya, sosial, politik, dan ekonomi bangsa lain dengan titik berat memahami adanya saling ketergantungan; (2) mempelajari berbagai cabang ilmu pengetahuan untuk digunakan sesuai dengan kebutuhan lingkungan setempat;

${ }^{38}$ Sardar, Rekayasa Masa Depan ..., h. 247. 
mengembangkan berbagai kemungkinan, kemampuan dan keterampilan untuk bekerja sama untuk mewujudkan kehidupan masyarakat dunia yang lebih baik. ${ }^{39}(4)$ menyertakan etika sosial dalam setiap lini perkembangan ilmu pengetahuan; (5) mengamalkan ajaran agama ${ }^{40}$ sebagai kontrol diri dalam mengejar kepuasan untuk mendapatkan nilai-nilai ketenangan dan kedamaian.

Berdasarkan ciri-ciri tersebut maka perlu disajikan sistem pendidikan yang bersifat interdisipliner, multidisipliner dan transdisipliner dengan kebijakan yang saling mengikat antara pemenuhan nilai-nilai sosial, agama, budaya, dan kebutuhan pasar. Melalui pemenuhan nilai ini pendidikan menjadi wadah dalam memelihara tatanan sosial yang berlaku dalam masyarakat. Hal ini menuntut transfer pengetahuan, keterampilan dan sikap keyakinan yang diperlukan masyarakat dari sutu generasi ke generasi selanjutnya. Oleh sebab itu, arah orientasi kurikulum pendidikan Islam hendaknya diformulasikan untuk membekali individu dasar-dasar hidup di dalam masyarakat, kewajiban dan hak-hak terhadapnya, serta memberi kaitan nurturant effect (efek pengiring) etika sosial di segala lini aktivitas kehidupan.

\footnotetext{
${ }^{39}$ Zamroni, Paradigma Pendidikan Masa Depan..., h. 91-92.

${ }^{40}$ Peran agama dalam percaturan globalisasi dapat menjadi landasan tindakan kebijaksanaan yang berperan sebagai unsur-unsur kontrol sosial (alamr bi al-ma'rūf wa al-nahy 'an al-munkar). Ini dapat dilakukan dengan (1) mempertebal dan memperkukuh iman kaum muslim sehingga tidak tergoyahkan oleh pengaruh-pengaruh negatif dari kemajuan ilmu pengetahuan dan teknologi atau paham-paham yang membahayakan negara, bangsa dan agama; (2) meningkatkan tata kehidupan umat dalam arti yang luas, dengan mengubah dan mendorong mereka untuk menyadari bahwa agama mewajibkan mereka untuk berusaha menjadikan hari esok lebih cerah dari hari ini. Ini tidak dapat dicapai kecuali dengan kerja keras serta kesadaran akan keseimbangan hidup dunia dan akhirat; dan (3) meningkatkan pembinaan akhlak umat Islam sehingga memiliki sikap dan prilaku yang baik dalam kehidupan beragama, bermasyarakat dan bernegara. Dengan itu dapat terwujud etos kerja dan ukhuwah Islamiyah dalam rangka mewujudkan kerukunan beragama. Lihat Shihab, Membumikan Al-Quran..., h. 392-393.
} 


\section{PENUTUP}

Sebagai penutup dari tulisan ini, perlu dikemukakan bahwa: pertama, pendidikan Islam dalam fungsinya sebagai transfer of value, memberikan kontribusi terhadap proses kulturisasi dalam mengembangkan kepribadian dengan meletakkan etika untuk membangun diri individu, keluarga dan masyarakat berdasarkan nilai-nilai religiusitas dan normativitas yang berlaku di masyarakat; dan kedua, pendidikan Islam menekankan pentingnya fungsi etika sosial sebagai bentuk nilai yang menjadi paradigma dalam mengarahkan seseorang berinteraksi dengan lingkungan sosialnya dan juga sebagai sasaran ibadah utama karena merupakan muara kesempurnaan ketakwaan seseorang yang diimplementasikan dalam kehidupan sosial melalui rekonstruksi budaya.

\section{DAFTAR PUSTAKA}

Abdullah, Abdul Rahman Salih, Education Theory of Quranic Outlook, Makkah al-Mukarramah: Umm al-Qura University, 1402/1982.

Aly, Hery Noer dan Munzier S., Watak Pendidikan Islam, Jakarta: Friska Agung Insani, 2003.

Ashraf, Ali, Horison Baru Pendidikan Islam, terj. Sari Siregar, t.t.p.: Pustaka Firdaus, 1993.

Azra, Azyumardi. Pendidikan Islam: Tradisi dan Modernisasi Menuju Milenium Baru, Jakarta: Logos Wacana Ilmu, 1999.

Barnadib, Imam. Dasar-Dasar Kependidikan: Memahami Makna dan Perspektif Beberapa Teori Pendidikan, Jakarta: Ghalia Indonesia, 1996

Boisard, Marcel A., Humanisme dalam Islam (L' Humanisme De L'Islam), alih bahasa M. Rasjidi, Jakarta:Bulan Bintang, 1980.

Depag RI, Al-Quran dan Terjemahanya, Bandung: Diponegoro, 2000.

Hidayat, Komaruddin. "Ethos Masyarakat Utama" dalam M. Yunan Yusuf, dkk. (eds.), Masyarakat utama: Konsepsi dan Strategi, Jakarta: PERKASA bekerjasama dengan LPP-PP Muhammadiyah, 1995. 
Husein, Syed Sajjad dan Ashraf, Syed Ali. Menyongsong Keruntuhan Pendidikan Islam, terj. Rahmani Astuti, Cet. 5, Bandung: Gema Risalah Press, 1994.

Mashuri. Kebijaksanaan dan Langkah-langkah Pembaharuan Pendidikan, Jakarta: Departemen Pendidikan dan Kebudayaan, 1973.

Merrill, F.E and Elderdge,H.W. Culture and Sociology, New York: Prentice Hall, Inc., 1953.

Muhadjir, Noeng. "Glossry" bagian keempat Analisis dan refleksi dalam Pedoman Pelaksanaan Penelitian Tindakan Kelas (PTK), Dirjen Dikti Depdikbud \& IKIP Yogyakarta, 1996/1997.

Muhadjir, Noeong, Metodologi Penelitian Kebijakan: Telaah Cross Disiplin, Yogyakarta: Rake Sarasin, 1998.

Muhaimin, Rekonstruksi Pendidikan Islam: Dari Paradigma Pengembangan, Manajemen Kelembagaan, Kurikulum hingga Strategi Pembelajaran. Jakarta: PT RajaGrafindo Persada, 2009.

Mulkhan, Abdul Munir. Kearifan Tradisional: Agama bagi Manusia atau Tuhan, disunting Anas Hidayat \& Sobirin Malian, Yogjakarta: UII Press, 2000.

Mulkhan, Abdul Munir, Nalar Spiritual Pendidikan Islam: Solusi Problem Filosofis Pendidikan Islam, Yogyakarta: Tiara Wacaana, 2002.

Muntasir, M. Saleh Mencari Evidensi Islam: Analisa Awal Sistem Filsafat, Strategi dan Methodologi Pendidiakan Islam, Jakarta: CV. Rajawali, 1985.

Sardar, Ziauddin, Rekayasa Masa Depan Peradaban Muslim, terj. Rahmani Astuti, cet. ke-4; Bandung: Mizan, 1993

Shihab, M. Quraish. Membumikan Al-Quran: Fungsi dan Peran Wahyu dalam Kehidupan Masyarakat, Bandung: Mizan,1992.

Tobroni dan Arifin, Syamsul, Islam, Pluralisme Budaya dan Politik: Refleksi Teologi untuk Aksi dalam Keberagaman dan Pendidikan, Yogyakarta: Sipress, 1994.

Zamroni, Paradigma Pendidikan Masa Depan, Yogyakarta: Bigraf Publising, 2000. 